Article

\title{
Evaluation of Hybrid Constructed Wetland Performance and Reuse of Treated Wastewater in Agricultural Irrigation
}

\author{
Michal Šereš ${ }^{1,2}$, Petra Innemanová ${ }^{1,2}$, Tereza Hnátková ${ }^{1,3}$, Miloš Rozkošný ${ }^{4}$, Alexandros Stefanakis ${ }^{5}(\mathbb{D}$, \\ Jaroslav Semerád ${ }^{6}\left(\mathbb{C}\right.$ and Tomáš Cajthaml ${ }^{2,6, *}$ (i) \\ 1 Dekonta, a.s., Dřetovice 109, 27342 Stehelčeves, Czech Republic; michal.seres@dekonta.cz (M.Š.); \\ innemanova@dekonta.cz (P.I.); hnatkova@dekonta.cz (T.H.) \\ 2 Institute for Environmental Studies, Faculty of Science, Charles University, Benátská 2, \\ 12801 Prague, Czech Republic \\ 3 Faculty of Environmental Sciences, Czech University of Life Sciences Prague, Kamýcká 129, \\ 16521 Prague, Czech Republic \\ 4 TGM Water Research Institute, Mojmírovo nám. 16, 61200 Brno, Czech Republic; milos.rozkosny@vuv.cz \\ 5 School of Environmental Engineering, Technical University of Crete, 73100 Chania, Greece; \\ astefanakis@enveng.tuc.gr \\ 6 Institute of Microbiology of the Czech Academy of Sciences, Vídeňská 1083, 14220 Prague, Czech Republic; \\ jaroslav.semerad@biomed.cas.cz \\ * Correspondence: cajthaml@biomed.cas.cz
}

Citation: Šereš, M.; Innemanová, P.; Hnátková, T.; Rozkošný, M.;

Stefanakis, A.; Semerád, J.; Cajthaml, T. Evaluation of Hybrid Constructed Wetland Performance and Reuse of Treated Wastewater in Agricultural Irrigation. Water 2021, 13, 1165. https://doi.org/10.3390/w13091165

Academic Editor: Andreas N. Angelakis

Received: 14 March 2021

Accepted: 19 April 2021

Published: 23 April 2021

Publisher's Note: MDPI stays neutral with regard to jurisdictional claims in published maps and institutional affiliations.

Copyright: (c) 2021 by the authors. Licensee MDPI, Basel, Switzerland. This article is an open access article distributed under the terms and conditions of the Creative Commons Attribution (CC BY) license (https:/ / creativecommons.org/licenses/by/ $4.0 /)$.
Abstract: Agriculture is being negatively affected by the decrease in precipitation that has been observed over the last few years. Even in the Czech Republic, farmers are being urged to irrigate their fields despite the fact that sources of water for irrigation are rapidly being depleted. This problem might be partially solved via the reuse of treated wastewater in certain agricultural sectors. However, the public perception of the reuse of wastewater remains negative primarily due to unknown risks to the environment and public health. To overcome this barrier, a semi-operated irrigation field was established at Kostelec nad Ohří in the Central Bohemian region of the Czech Republic and planted with common garden crops such as tomatoes (Lycopersicon esculentum), potatoes (Solanum tuberosum) and lettuces (Lactuca sativa L.) irrigated with two different water sources, i.e., treated wastewater from a local nature-based treatment system, a hybrid constructed wetland (HCW), and local fresh water from well. The HCW was put into operation in 2017 and was reconstructed in 2018 and includes both horizontal and vertical flow beds; the trial irrigation field was added in the same year. The reconstruction of the facility significantly enhanced the removal efficiency with respect to all monitored parameters, e.g., biochemical oxygen demand $\left(\mathrm{BOD}_{5}\right)$, chemical oxygen demand (COD), $\mathrm{N}-\mathrm{NH}_{4}{ }^{+}$, total $\mathrm{N}$ and the suspended solids (TSS), except for total P. The HCW also ensured the significant removal of several observed pathogenic microorganisms (E. coli, intestinal enterococci and thermotolerant coliforms). During the 2018 and 2019 growing seasons, we observed the significantly enhanced growth of the crops irrigated with wastewater from the HCW due to the fertilizing effect. The risks associated with the contamination of crops irrigated with treated water are not negligible and it is necessary to pay sufficient attention to them, especially when introducing irrigation with wastewater into practice.

Keywords: hybrid constructed wetland; nature-based solutions; wastewater reuse; nutrient recovery; agriculture; sustainability; horizontal flow; vertical flow

\section{Introduction}

Due to the increasing need for irrigation worldwide aimed at enhancing crop yields, the importance of sustainable water use is attracting ever-increasing attention. Moreover, this trend is gradually moving from dry to relatively wet regions. One potentially applicable, and at the same time constantly available, source of water comprises treated 
wastewater (WW). While in dry areas the main driver for WW reuse comprises a lack of fresh water [1,2], in wet areas environmental concerns related to WW discharge into the environment predominate [3]. The reclamation of WW is considered a sustainable practice towards a circular water economy and has the potential to solve several problems simultaneously. Moreover, wastewater is favorably regarded in terms of its nutritious value which allows its use as an alternative type of fertilizer able to enhance crop productivity [4]. However, WW reuse in agriculture also presents a number of significant risks linked principally to the presence of pathogenic microorganisms and their potential spread to crops and the environment [5], an increase in bacteria antibiotic resistance in irrigated soil $[6,7]$ and the presence of various organic pollutants such as pharmaceuticals [8] and per- and polyfluoroalkyl substances (PFAS) [9] in the WW even following treatment. Therefore, a well-proved WW treatment approach must be in place prior to its use for field irrigation purposes.

Due to the high level of the removal efficiency of organic pollutants, nutrients, pathogenic bacteria [10] and micropollutants, hybrid constructed wetlands (HCW) have the potential to offer an attractive solution to the treatment of WW for reclamation purposes [11]. HCW are a nature-based solution for wastewater management and are generally characterized as sustainable systems that provide effective treatment combined with a minimum environmental footprint and a series of ecosystem services [12]. The use of HCW for the treatment of various types of complex wastewaters commenced at the end of the 20th century [13]. The main principle of hybrid systems is that they combine various types of constructed wetlands placed in series, thus enabling them to effectively treat several types of wastewater, e.g., domestic wastewater [14], livestock production wastewater [15,16], mixed domestic and agro-industrial wastewater [17], grey water [18] and agricultural runoff polluted with pesticides [19]. They have also proved effective in the successful treatment of WW containing organic micropollutants [20] and pharmaceutical and personal care products (PPCPs) [21]. In addition, the nutrients that remain following the treatment of WW have the potential to serve for the fertilization of crops [4,22].

This study focused on the operational efficiency of a full-scale HCW that is intermittently loaded with high volumes of moderately-polluted mixed WW discharged from a hotel, a restaurant and a brewery and the sequential reuse of the treated WW for the irrigation of various types of crops. The aim of the research was to determine whether such hybrid systems can be used as the final stage of the WW treatment procedure for the reclamation of water in the agricultural sector, fully respecting the various inherent risks (primarily microbial contamination) and taking into account the potential to make use of the nutritious value of the treated WW.

\section{Materials and Methods}

\subsection{Hybrid System Description}

The investigated hybrid system is located at Kostelec nad Ohří in the North Bohemia region of the Czech Republic. The HCW receives high volumes of moderately-polluted mixed WW from a hotel, a restaurant and a brewery. The system consists of 5 treatment stages: (i) a septic tank, (ii) a horizontal filter (HF), (iii) a vertical filter (VF), (iv) a combined filter consisting of an unsaturated vertically-flowed part and a saturated horizontally flowed part (HVF) and (v) stabilization pond (SP). The layout of the study location is in Figure 1 .

At the beginning of the operation of the HCW (hereafter start-up), the VF and HVF were operated in a fully saturated regime and thus anaerobic processes in the whole HCW were prevailing. The reconstruction of the hybrid system was performed at the end of 2017 and consisted of the introduction of the recirculation system and a change of the water filling regime at the VF and HVF. The newly introduced recirculation pump pumps the water from the SP to the HF with approximately $2 \mathrm{~L} \cdot \mathrm{s}^{-1}$ flow to prolong water retention in the whole system and also to retain the water under the anaerobic conditions of the HF for a longer time. The VF was equipped with a control shaft with a special dosing device 
that discontinuously doses $\sim 1.5 \mathrm{~m}^{3}$ of the WW each time the shaft becomes full. WW level in the VF was also decreased so the aerobic conditions could take place. Finally, the HVF was also equipped with the control shaft with a special dosing device that discontinuously doses $\sim 1.5 \mathrm{~m}^{3}$ of the WW onto the surface of the filter. The outlet pipe of the HVF is located approximately in the middle of the depth of the filter, thus resulting in the upper half of the filter being unsaturated (aerobic conditions) and the lower half being saturated (anaerobic conditions). Moreover, a small recirculation pump was installed in the outlet shaft for the recycling of a part of the water $\left(\sim 0.5 \mathrm{~L} \cdot \mathrm{s}^{-1}\right)$ back into the dosing shaft. The HCW has been in "full operation" since the beginning of 2018.
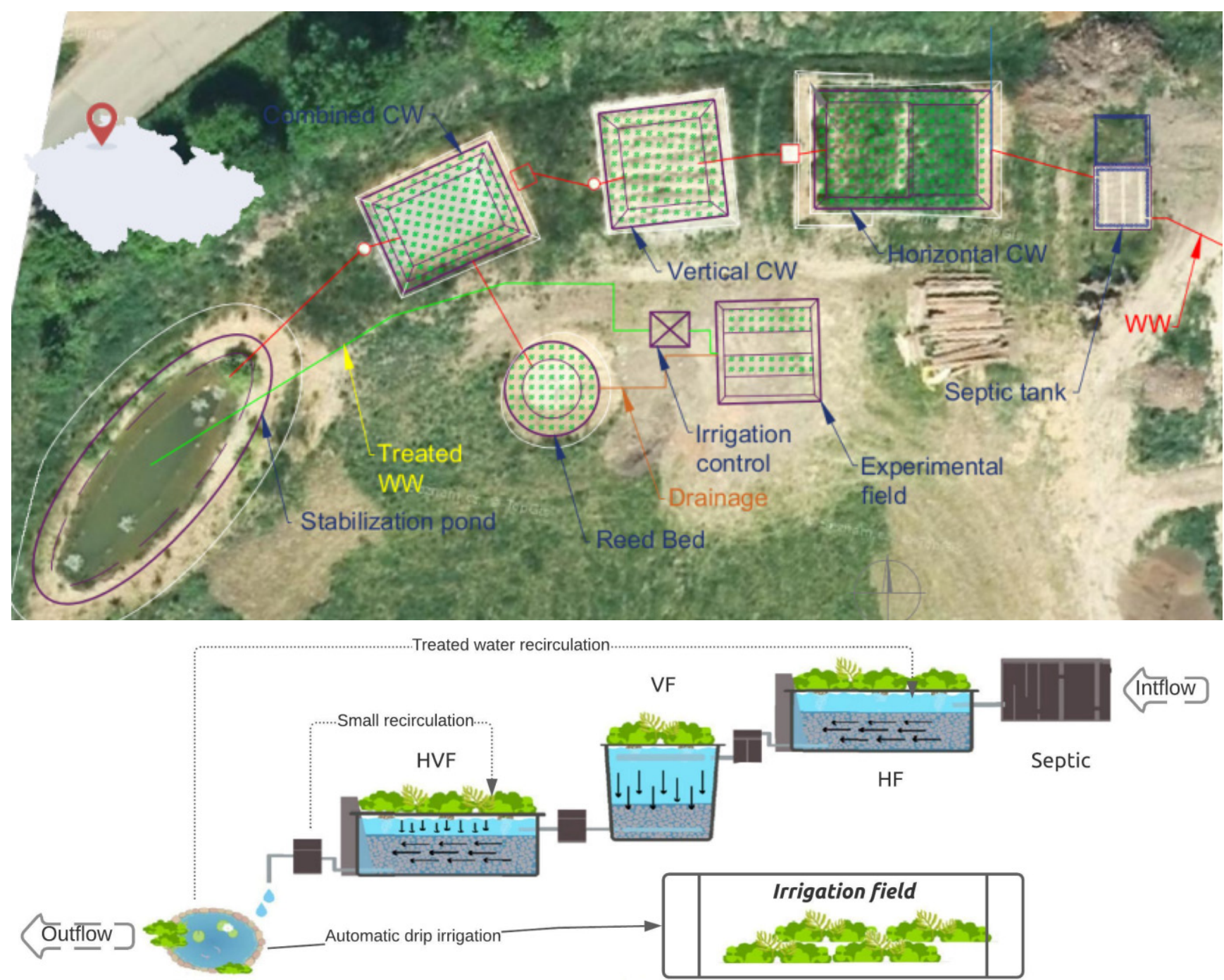

Figure 1. Map and layout of the hybrid system and the experimental irrigation field. $\mathrm{WW}=$ wastewater, $\mathrm{CW}=\mathrm{Constructed}$ Wetland, $\mathrm{HF}=$ horizontal filter, $\mathrm{VF}=$ vertical filter, $\mathrm{HVF}=$ combined filter.

The calculated maximal treatment capacity of the system is 150 population equivalent (PE) with a maximal daily wastewater inflow of $16.5 \mathrm{~m}^{3} \cdot \mathrm{d}^{-1}$. The wetland surface area of the hybrid system is $2.2 \mathrm{~m}^{2} \cdot \mathrm{PE}^{-1}$. The HCW basins are planted with common reed (Phragmites australis), reed canary grass (Phalaris arundinacea), common cattail (Typha latifolia), purple loosestrife (Lythrum salicaria) and yellow iris (Iris pseudacorus). More details on the treatment system are provided in Table 1. 
Table 1. Hybrid Constructed Wetland system parameters.

\begin{tabular}{|c|c|c|c|c|c|}
\hline HCW Part & Effective Area & Maximal Depth & Effective Volume & HLR & HRT \\
\hline & {$\left[\mathrm{m}^{2}\right]$} & [m] & {$\left[\mathrm{m}^{3}\right]$} & {$\left[\mathrm{cm} \cdot \mathrm{d}^{-1}\right]$} & [d] \\
\hline Septic tank (In) & 29.3 & 1.8 & 52.7 & - & 3.2 \\
\hline Horizontal filter (HF) & 150 & 0.9 & 33.1 & 10.0 & 2.0 \\
\hline Vertical filter (VF) & 81 & 1.3 & 26.2 & 18.5 & 1.6 \\
\hline Combined filter * (HVF) & 88 & $0.8+0.6$ & 34.6 & 17.1 & 2.1 \\
\hline Stabilization pond (SP) & 148.2 & 2 & 42.6 & - & 2.6 \\
\hline
\end{tabular}

* The first number refers to the unsaturated part; the second number refers to the saturated part; HCW = hybrid constructed wetland, HLR = hydraulic loading rate, HRT = hydraulic retention time.

Table 2 shows the limits for the quality of discharged wastewater. These limits are stricter in comparison with national legislation (Government Regulation No. 401/2015 Coll.) due to the permission to spray treated water on the operator's land. However, no limits are set for microbiological indicators and no national legislation imposes such limits.

Table 2. Limit values in $\mathrm{mg} \cdot \mathrm{L}^{-1}$ for the $\mathrm{HCW}$ in Kostelec nad Ohři (given by legal permit in accordance with Czech law).

\begin{tabular}{ccccccc}
\hline & BOD $_{\mathbf{5}}$ & COD & TSS & TP & TN & NH $_{\mathbf{4}}{ }^{+}-\mathbf{N}$ \\
\hline Limit-average & 30 & 130 & 30 & 8 & - & 15 \\
Limit-maximum & 40 & 150 & 40 & 10 & - & 20
\end{tabular}

BOD = biochemical oxygen demand, $\mathrm{COD}=$ chemical oxygen demand, TSS = total suspended solids, TN $=$ total nitrogen, $\mathrm{TP}=$ total phosphorus, $\mathrm{TK}=$ potassium, $\mathrm{NH}_{4}{ }^{+}-\mathrm{N}=$ ammonia nitrogen .

\subsection{Design of the Experimental Irrigation System}

The experimental irrigation system was constructed and put into operation at the beginning of 2018 following the commencement of the full operation of the HCW. Two sources of water were used for the experiments-fresh water from a well (hereinafter fresh water) and treated wastewater (treated WW) from the HCW collected in the SP.

The experimental field has an area of $49 \mathrm{~m}^{2}(7 \times 7 \mathrm{~m})$ and is built so that it is a waterproofed tub using plastic PVC foil with a depth of $0.7 \mathrm{~m}$. The original rendzina soil is located in this area. The initial quality of the soil is summarized in Table 3.

Table 3. Qualitative description of irrigated soil at the beginning of the experiment.

\begin{tabular}{cccccc}
\hline Parameter & Unit & Value & Parameter & Unit & Value \\
\hline Bulk density & $\mathrm{g} \cdot \mathrm{cm}^{-3}$ & 1.6 & $\mathrm{Mg}$ & $\mathrm{mg} \cdot \mathrm{kg}^{-1} \mathrm{DM}$ & 3590 \\
Porosity & $\%$ & 36.7 & $\mathrm{Na}$ & $\mathrm{mg} \cdot \mathrm{kg}^{-1} \mathrm{DM}$ & 273 \\
$\mathrm{pH}\left(25^{\circ} \mathrm{C}\right)$ & - & 8.2 & $\mathrm{~K}$ & $\mathrm{mg} \cdot \mathrm{kg}^{-1} \mathrm{DM}$ & 7550 \\
Conductivity & $\mu \mathrm{S} \cdot \mathrm{cm}^{-1}$ & 124 & $\mathrm{Ca}$ & $\mathrm{mg} \cdot \mathrm{kg}^{-1} \mathrm{DM}$ & 37,090 \\
Total phosphorus & $\mathrm{mg} \cdot \mathrm{kg}^{-1} \mathrm{DM}$ & 571 & $\mathrm{Cl}^{-}$ & $\mathrm{mg} \cdot \mathrm{kg}^{-1} \mathrm{DM}$ & 20 \\
Total nitrogen & $\mathrm{mg} \cdot \mathrm{kg}^{-1} \mathrm{DM}$ & 265 & $\mathrm{~S}$ & $\mathrm{mg} \cdot \mathrm{kg}^{-1} \mathrm{DM}$ & 291 \\
Total organic carbon & $\%$ of DM & 35,480 & $\mathrm{~B}$ & $\mathrm{mg} \cdot \mathrm{kg}^{-1} \mathrm{DM}$ & 28.5 \\
\hline
\end{tabular}

The experimental area was divided into four $1.5 \mathrm{~m}$-wide plots, of which two were planted with various model crops and two remained unplanted (control). Treated WW and fresh water were each applied to one of the planted and one of the unplanted plots, thus creating four differing treatment areas. Four drainage pipes connected to the sampling shafts were positioned so as to collect any excess water that collected beneath the plots. An irrigation control system fitted with a Hunter I-Core (Hunter Industries Inc., San Marcos, CA, USA) control unit was installed in the service building adjacent to the field so as to ensure the automatic application of the irrigation water to the plots independently. The control system was equipped with a rain sensor that automatically shut down the irrigation system in the event of rainfall (sensors lower limit $>3 \mathrm{~mm}$ ), the aim of which was to prevent the leakage of nutrients and, potentially, pathogenic microorganisms and 
hazardous substances into the drainage system and, further, to the surface water. The control system was connected to two water pumps (DAB Pumps, Mestrino, Italy) intended for the pumping of the water sources into the drip irrigation system. The pumps were equipped with 1" disk filters so as to prevent the clogging of the drippers. Drip irrigation hoses were installed in each section of the irrigation field in the form of three parallel lines. The spacing of the drippers was set at $40 \mathrm{~cm}$, which also determined the distance between the planted crops in the 2 planted plots. The plants were irrigated between June and October in both seasons.

The experimental field was planted with common garden crops, one variety of each. In 2018 tomatoes (Solanum lycopersicum L.), the TORO F1 variety, were planted, whereas in 2019, three crops were planted; tomatoes (Solanum lycopersicum L.), the Tornado variety; potatoes (Solanum tuberosum), the Rosara variety; and lettuces (Lactuca sativa L.), the Capitate variety.

\subsection{Crop Sampling and Harvesting}

Each crop was harvested and sampled according to its maturation characteristics. The tomatoes were harvested at the fully red stage of maturity between August and September, following which they were transported in a cooling box to the laboratory. The harvesting procedure included a mixture of the mature tomatoes, and the weight of the harvest and number of tomatoes were recorded. After each harvest, three mixed samples (replicas) per treatment, each containing at least 3 randomly-picked tomatoes and each collected from different plants were analysed in terms of the pre-determined parameters. During seasons 2018 and 2019, 12 mixed samples (72 tomatoes) and 24 mixed samples (135 tomatoes), respectively were analysed for the selected parameters.

The potatoes were harvested in September 2019. The whole harvest of potatoes was mechanically cleaned of soil and three mixed samples from each variant containing five potatoes from randomly-selected plants were dispatched for microbial contamination testing. The number of potatoes and the weight of the harvest were calculated following cleaning with tap water. The weight of the previously collected samples was then added to the sum. A further three mixed samples were then prepared from randomly-picked potatoes from each variant for the completion of the analysis.

The lettuces from each treatment were harvested in June 2019. The above-ground biomass was weighed and three samples per treatment were prepared for analysis in the form of three mixed samples containing randomly picked parts from each plant.

\subsection{Laboratory Analysis}

\subsubsection{Water Source Quality}

The performance of the HCW system was evaluated based on samples extracted regularly every two months from three sampling points-the inlet to the septic tank (In), the outlet from the HVF (Out) and a mixed sample from the stabilization pond (SP). No inlet samples were taken at the start of operation. Fresh water from the well was collected from the pumping reservoir. Composite water samples collected over two hours were stored at $10^{\circ} \mathrm{C}$ prior to the analysis. The chemical oxygen demand (COD, $\mathrm{mg} \cdot \mathrm{L}^{-1}$ ) was measured using the dichromate method following ISO guideline 6060 [23]. The biochemical oxygen demand $\left(\mathrm{BOD}_{5}, \mathrm{mg} \cdot \mathrm{L}^{-1}\right)$ was measured following ISO guidelines 5815-1 [24] and 5815-2 [25]. The total phosphorus (TP, $\mathrm{mg} \cdot \mathrm{L}^{-1}$ ) was measured using the ammonium molybdate spectrometric method following ISO guideline 6878 [26]. The total nitrogen (TN, $\mathrm{mg} \cdot \mathrm{L}^{-1}$ ) was measured following European norm EN 12,260 [27]. The ammonia nitrogen $\left(\mathrm{NH}_{4}{ }^{+}-\mathrm{N}, \mathrm{mg} \cdot \mathrm{L}^{-1}\right)$ was measured by means of the manual spectrometric method following ISO guideline 7150 [28]. The suspended solids (TSS, $\mathrm{mg} \cdot \mathrm{L}^{-1}$ ) were measured via filtration through glass-fibre filters with pore size $1.5 \mu \mathrm{m}$ following ISO guideline 11923:1997 [29]. The following parameters were evaluated in order to describe the microbial contamination of the water sources: total coliforms (TC, CFU. $\mathrm{mL}^{-1}$ ), thermotolerant coliforms (TTC, $\mathrm{CFU} \cdot \mathrm{mL}^{-1}$ ) and Escherichia coli $\left(\mathrm{EC}, \mathrm{CFU} \cdot \mathrm{mL}^{-1}\right)$, each determined following Czech norm 
ČSN 757837 [30]. Intestinal enterococci (IE, CFU $\cdot \mathrm{mL}^{-1}$ ) was determined following ISO guideline 7899-2 [31].

\subsubsection{Plant Analysis}

The harvested plants and fruit were cut on a sterile surface under a laminar airflow hood. The following parameters were determined for all the collected samples: the number of plants/fruit, the weight of the harvest, the weight of the plants/fruit and the dry matter content (DM, \%) using the gravimetric method following drying at $60{ }^{\circ} \mathrm{C}$ to a constant weight. Some of the samples were tested for microbial contamination; the total coliforms (TC, CFU. $\mathrm{g}^{-1} \mathrm{DM}$ ), thermotolerant coliforms (TTC, CFU $\cdot \mathrm{g}^{-1} \mathrm{DM}$ ), Escherichia coli $\left(\mathrm{EC}, \mathrm{CFU} \cdot \mathrm{g}^{-1} \mathrm{DM}\right)$ and intestinal enterococci (IE, CFU. $\mathrm{g}^{-1} \mathrm{DM}$ ) were determined using a modified version of the determination method in water mentioned above. The modification of the method comprised the preparation of a leachate from $90 \mathrm{~mL}$ of sterile physiological solution in tap water and $10 \pm 0.5 \mathrm{~g}$ of the sample. The resulting suspension was shaken intensively, allowed to settle for $5 \mathrm{~min}$ and then analysed. The results took into account the dilution ratios. The rest of the biomass samples were tested for total nitrogen (TN, $\mathrm{mg} \cdot \mathrm{kg}^{-1}$ ) via the determination of the TN content by means of combustion according to the Dumas principle (ISO guideline 16634:2) [32], and total phosphorus (TP, $\mathrm{mg} \cdot \mathrm{kg}^{-1}$ ) and potassium (TK, $\mathrm{mg} \cdot \mathrm{kg}^{-1}$ ) via the determination of selected elements by means of inductively coupled plasma optical emission spectrometry following ISO guideline 11885 [33] following homogenization and mineralization in hydrogen peroxide and acids.

\subsection{Statistical Analysis}

The results were statistically evaluated using $R$ software, version 4.0.2. The comparison of the HCW removal efficiency was tested by means of non-parametric Kruskall-Wallis tests with evaluation at the $p=0.05$ level.

\section{Results}

\subsection{HCW System Performance \\ 3.1.1. Organic Pollution}

The HCW system at Kostelec nad Ohři did not perform well during the start-up phase. The removal of $\mathrm{BOD}_{5}$ and $\mathrm{COD}$ was not sufficient and both parameters exceeded the set outflow limits. The concentrations of $\mathrm{BOD}_{5}$ during the monitoring period are shown in Figures 2 and 3. It is clear that during the start-up phase and the first four months of full-scale operation the limits were exceeded on a regular basis. The average outlet concentration in the start-up phase was $30.7 \pm 18.7 \mathrm{mg} \cdot \mathrm{L}^{-1}$. Following reconstruction and the stabilization of full-scale operation, the average outlet concentrations dropped to $5.6 \pm 5.0 \mathrm{mg} \cdot \mathrm{L}^{-1}$.

Similar trends can be observed with respect to COD (see Figures 2 and 3). The outlet concentration of COD reached a maximum of $290 \mathrm{mg} \cdot \mathrm{L}^{-1}$ once during the start-up phase, with the average outlet concentration being $134.9 \pm 83.9 \mathrm{mg} \cdot \mathrm{L}^{-1}$. Following reconstruction, the average outlet concentration dropped to $53.0 \pm 42.6 \mathrm{mg} \cdot \mathrm{L}^{-1}$.

The outlet concentrations of $\mathrm{BOD}_{5}$ differed significantly $(p<0.05)$ between the two monitored periods (see Figure 3), corresponding to well-performed intensification. We observed a significant statistical difference between the Inlet (average concentrations of $530.7 \pm 108.3 \mathrm{mg} \cdot \mathrm{L}^{-1}$ ) and the two outlet sampling points. Nevertheless, the concentrations of $\mathrm{BOD}_{5}$ at the Out and SP did not differ significantly $(p>0.05)$. The $\mathrm{BOD}_{5}$ removal efficiency during the full operation was $99.0 \pm 0.9 \%$ at the outlet and $95.5 \pm 4.9 \%$ in the stabilization pond, thus indicating that the stabilization pond did not improve the water quality in terms of $\mathrm{BOD}_{5}$. This was most probably due to the blooming, die-off and degradation of aquatic algae. Similar effects were observed in other hybrid constructed wetlands [17]. 

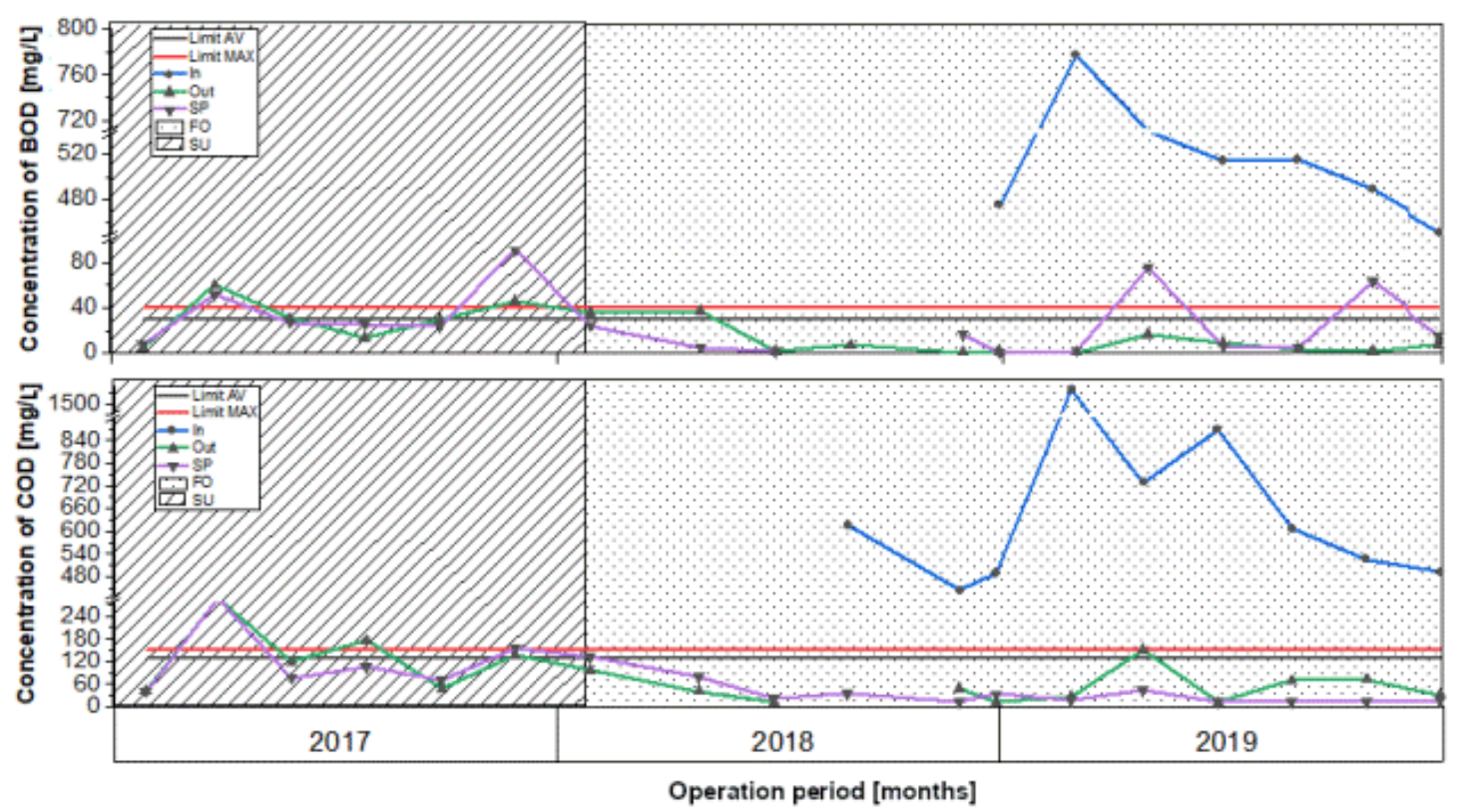

Figure 2. $\mathrm{BOD}_{5}$ (upper) and $\mathrm{COD}$ (lower) concentration development. $\mathrm{AV}=$ average limit, $\mathrm{MAX}=$ maximal limit, In = inlet, Out $=$ outlet, $\mathrm{SP}=$ stabilization pond, $\mathrm{FO}=$ full operation, $\mathrm{SU}=$ start-up phase.
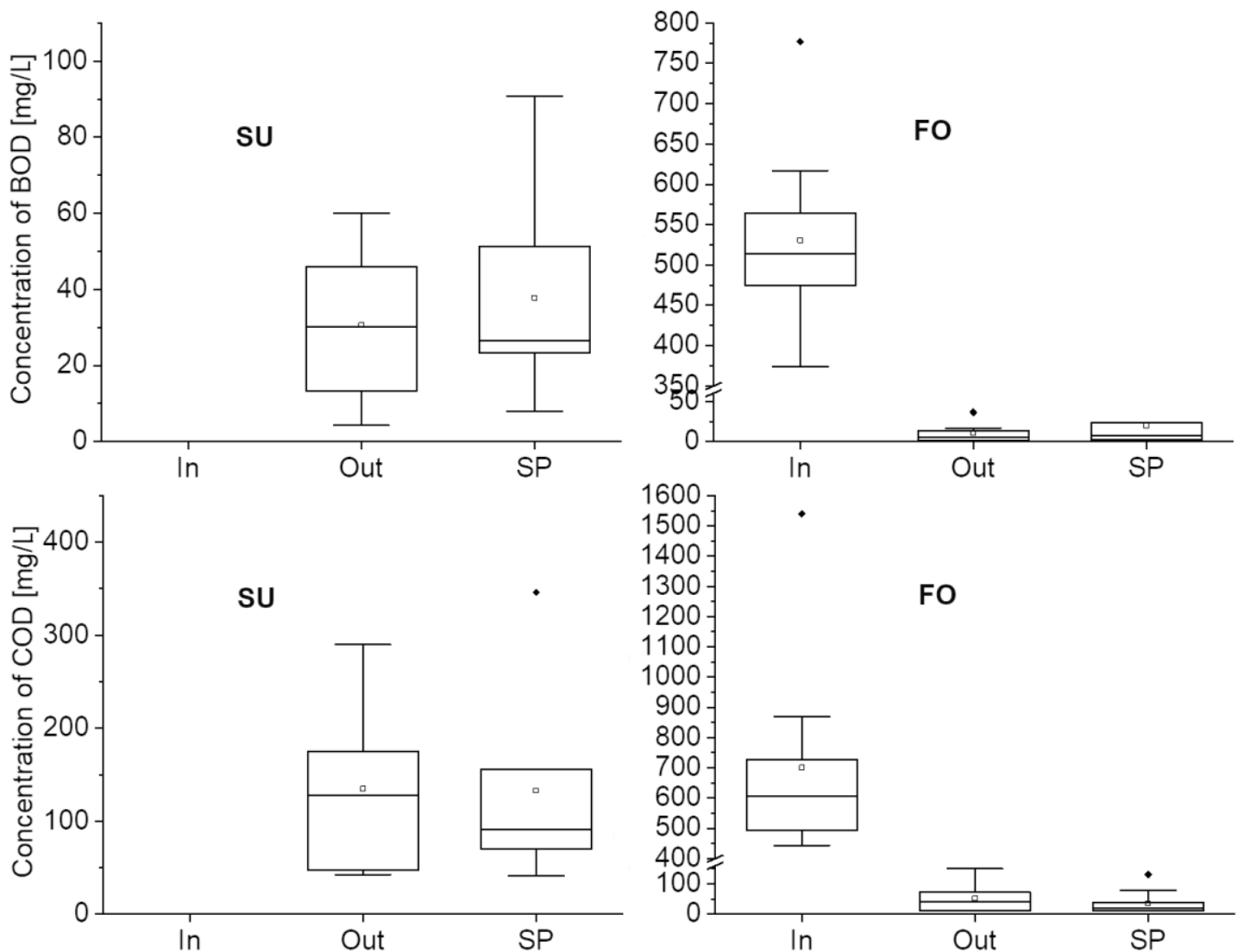

Figure 3. $\mathrm{BOD}_{5}$ and $\mathrm{COD}$ concentration comparison during $\mathrm{SU}=$ start-up phase and $\mathrm{FO}=$ full-scale operation, $\mathrm{In}=$ inlet, Out $=$ outlet, $\mathrm{SP}=$ stabilization pond.

The average COD inlet concentration of $700.8 \pm 322.4 \mathrm{mg} \cdot \mathrm{L}^{-1}$ differed significantly from the two outlet sampling point concentrations. Again, the concentrations at the Out and SP did not differ significantly $(p>0.05)$. The COD removal efficiency during the full 
operation was $91.4 \pm 6.4 \%$ at the outlet and $96.5 \pm 2.0 \%$ in the stabilization pond. The quality of the water in terms of COD improved in the SP.

\subsubsection{Nutrients}

The ammonia nitrogen and total phosphorus concentrations were both considered limiting parameters with respect to the environmental permit for full operation. Ammonia nitrogen comprised an average of $85 \%$ of the TN concentration at the inlet and only $26 \%$ of the TN at the outlet, indicating the effective nitrification of ammonia along the system and the respective conversion to nitrate. Both parameters exhibited similar trends during the monitoring period (see Figures 4 and 5).

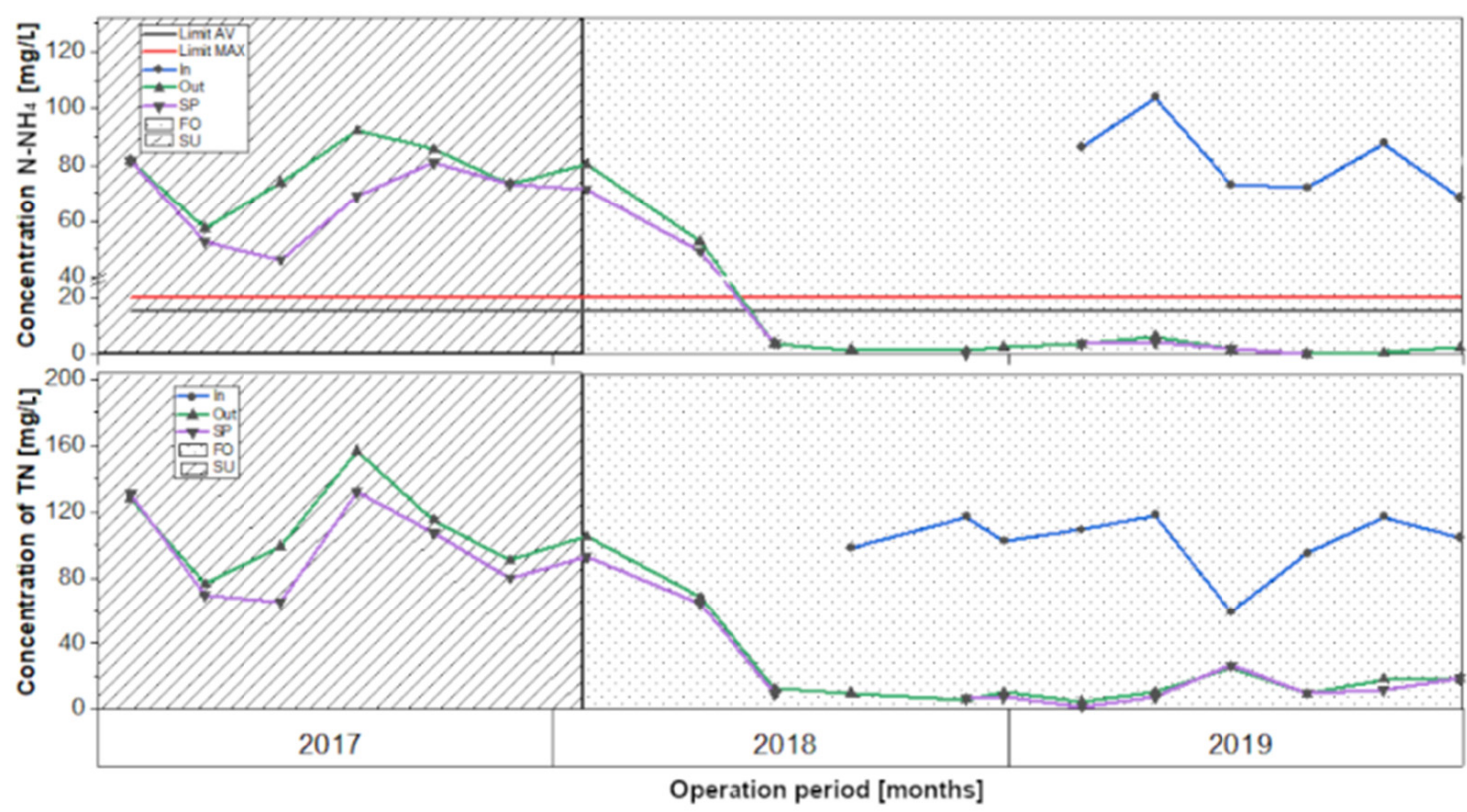

Figure 4. $\mathrm{N}-\mathrm{NH}_{4}$ (upper) and $\mathrm{TN}$ (lower) concentration development. $\mathrm{AV}=$ average limit, $\mathrm{MAX}=$ maximal limit, In = inlet, Out $=$ outlet, $\mathrm{SP}=$ stabilization pond, $\mathrm{FO}=$ full operation, $\mathrm{SU}=$ start-up phase.

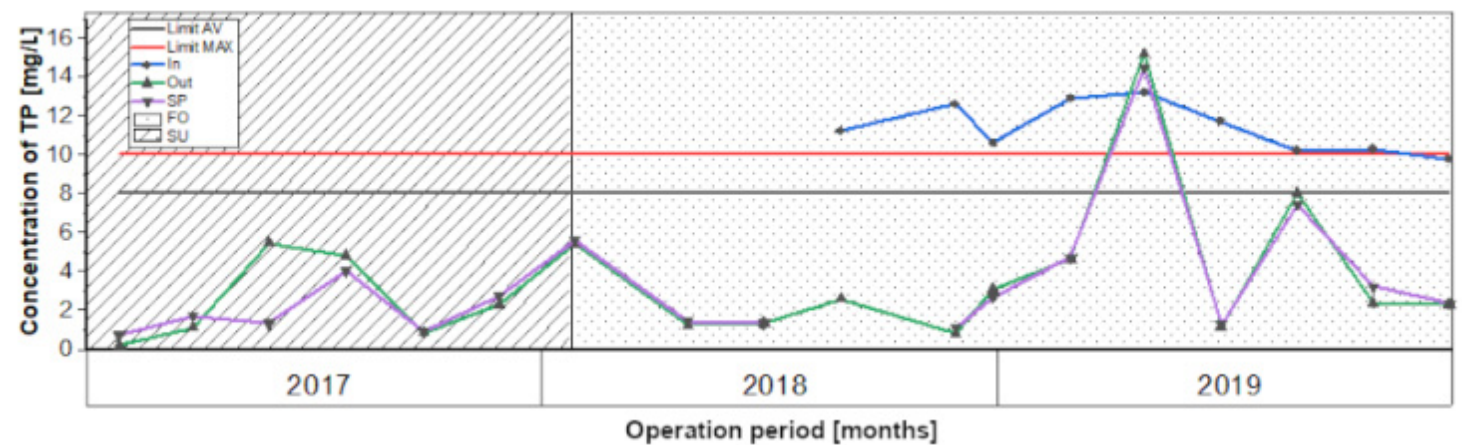

Figure 5. TP concentration development. $\mathrm{AV}=$ average limit, $\mathrm{MAX}=$ maximal limit, $\mathrm{In}=$ inlet, Out $=$ outlet, $\mathrm{SP}=$ stabilization pond, $\mathrm{FO}=$ full operation, $\mathrm{SU}=$ start-up phase.

As can be seen in Figure 4 below, the ammonia was not removed until the completion of reconstruction and the introduction of aerobic processes in the vertical filters. After four months of full operation, the gradual development of plant growth in the modified system resulted in the establishment of aerobic processes that promoted the nitrification process [12], which led to the removal of the ammonia and TN in the HCW.

The average inlet concentrations of ammonia and the TN were $81.8 \pm 12.3 \mathrm{mg} \cdot \mathrm{L}^{-1}$ and $102.1 \pm 17.3 \mathrm{mg} \cdot \mathrm{L}^{-1}$, respectively. The efficiency of the removal of ammonia was 
$97.4 \pm 2.0 \%$ with no differences being observed between the Out and the SP. The main removal processes thus occurred in the VF and HVF. The TN removal efficiency was $86.3 \pm 11.2 \%$ at the outlet and $87.1 \pm 13.0 \%$ in the SP. Denitrification under the predominantly anaerobic environment of the SP might explain the slight increase in the removal of $\mathrm{TN}$ in the stabilization pond.

The average outlet concentration of $\mathrm{N}-\mathrm{NH}_{4}{ }^{+}$was $77.3 \pm 11.0 \mathrm{mg} \cdot \mathrm{L}^{-1}$ during the start-up phase and only $2.1 \pm 1.8 \mathrm{mg} \cdot \mathrm{L}^{-1}$ during full operation (see Figure 5); therefore, significant statistical differences $(p>0.05)$ between the inlet and outlet concerned only full-scale operation. However, the differences between the results at the outlet sampling points evinced no statistical difference $(p>0.05)$; thus, the SP exerted no effect on the removal of ammonia.

The outlet concentrations of phosphorus during the whole of the monitoring period suggested that removal was independent of the operation phase $(p>0.05$ for the comparison of both phases). This should be attributed to the fact that phosphorus removal in $\mathrm{CW}$ systems mostly takes place through abiotic processes such as adsorption to substrate media and roots and less through biodegradation and plant uptake $[11,34]$. The average TP concentration in the start-up phase was $2.5 \pm 2.0 \mathrm{mg} \cdot \mathrm{L}^{-1}$ at the outlet and $1.9 \pm 1.1 \mathrm{mg} \cdot \mathrm{L}^{-1}$ in the SP (see Figure 5). During full-scale operation, the concentration even increased to $4.5 \pm 4.3 \mathrm{mg} \cdot \mathrm{L}^{-1}$ at the outlet and $4.7 \pm 4.2 \mathrm{mg} \cdot \mathrm{L}^{-1}$ in the SP.

The efficiency of the removal of TP reached $86.3 \pm 11.2 \%$ at the Out and $87.1 \pm 13.0 \%$ in the SP during full operation, which was a very favorable result and probably due to the fresh and unsaturated media used in the beds. Experience with other CW systems dictates that TP removal will drop with time as the active adsorption sites of the substrate will gradually become saturated with phosphorus.

\subsubsection{Suspended Solids}

In a similar way to the phosphorus, the removal of total suspended solids was independent of the operational phase (see the outlet concentrations in Figure 6) due to the fact that constructed wetlands are generally very efficient in terms of the removal of TSS through filtration processes that occur within the whole of the wetland filter body [2]. The average inlet concentrations were $246.4 \pm 117.2 \mathrm{mg} \cdot \mathrm{L}^{-1}$ with a removal efficiency rate of $96.0 \pm 2.3 \%$ at the outlet.

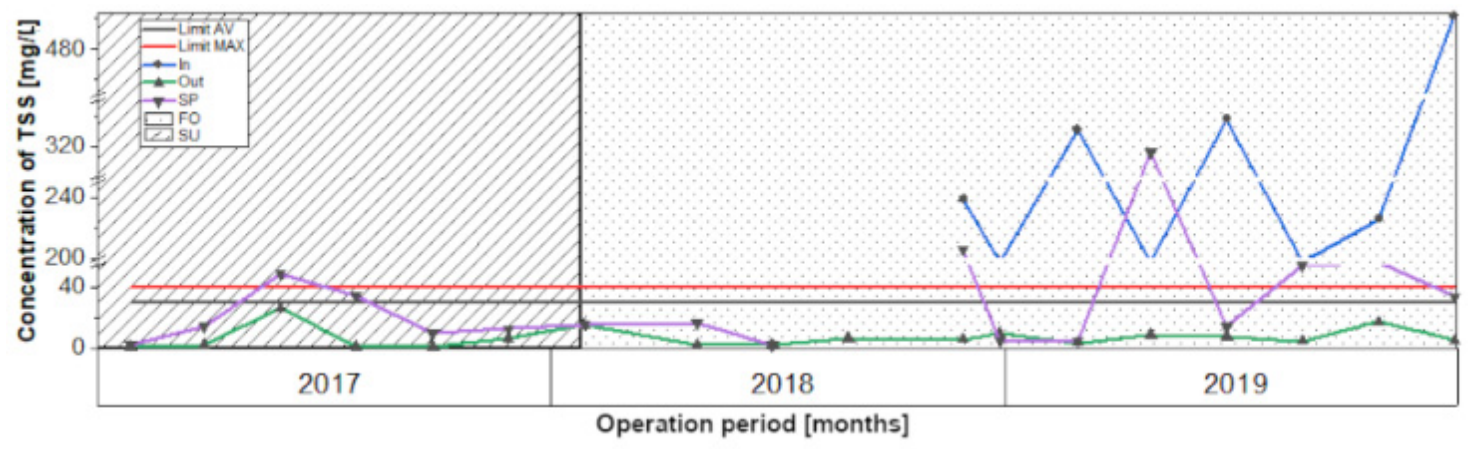

Figure 6. TSS concentration development. $\mathrm{AV}=$ average limit, $\mathrm{MAX}=$ maximal limit, $\mathrm{In}=$ inlet, Out $=$ outlet, $\mathrm{SP}=$ stabilization pond, $\mathrm{FO}=$ full operation, $\mathrm{SU}=$ start-up phase.

As can be seen in Figure 7, the concentration of TSS during the start-up phase and during full operation did not differ significantly $(p>0.05)$; however, statistically differing values were observed between the various sampling points. The average concentration of TSS before and after reconstruction was $6.4 \pm 9.1 \mathrm{mg} \cdot \mathrm{L}^{-1}$ and $7.9 \pm 3.8 \mathrm{mg} \cdot \mathrm{L}^{-1}$, respectively. On the other hand, the average concentrations of TSS in the stabilization pond before and after reconstruction were $20.5 \pm 16.1 \mathrm{mg} \cdot \mathrm{L}^{-1}$ and $101.0 \pm 109.1 \mathrm{mg} \cdot \mathrm{L}^{-1}$, respectively. This increase was due primarily to the growth of algae, which resulted in the deterioration of the water quality. 

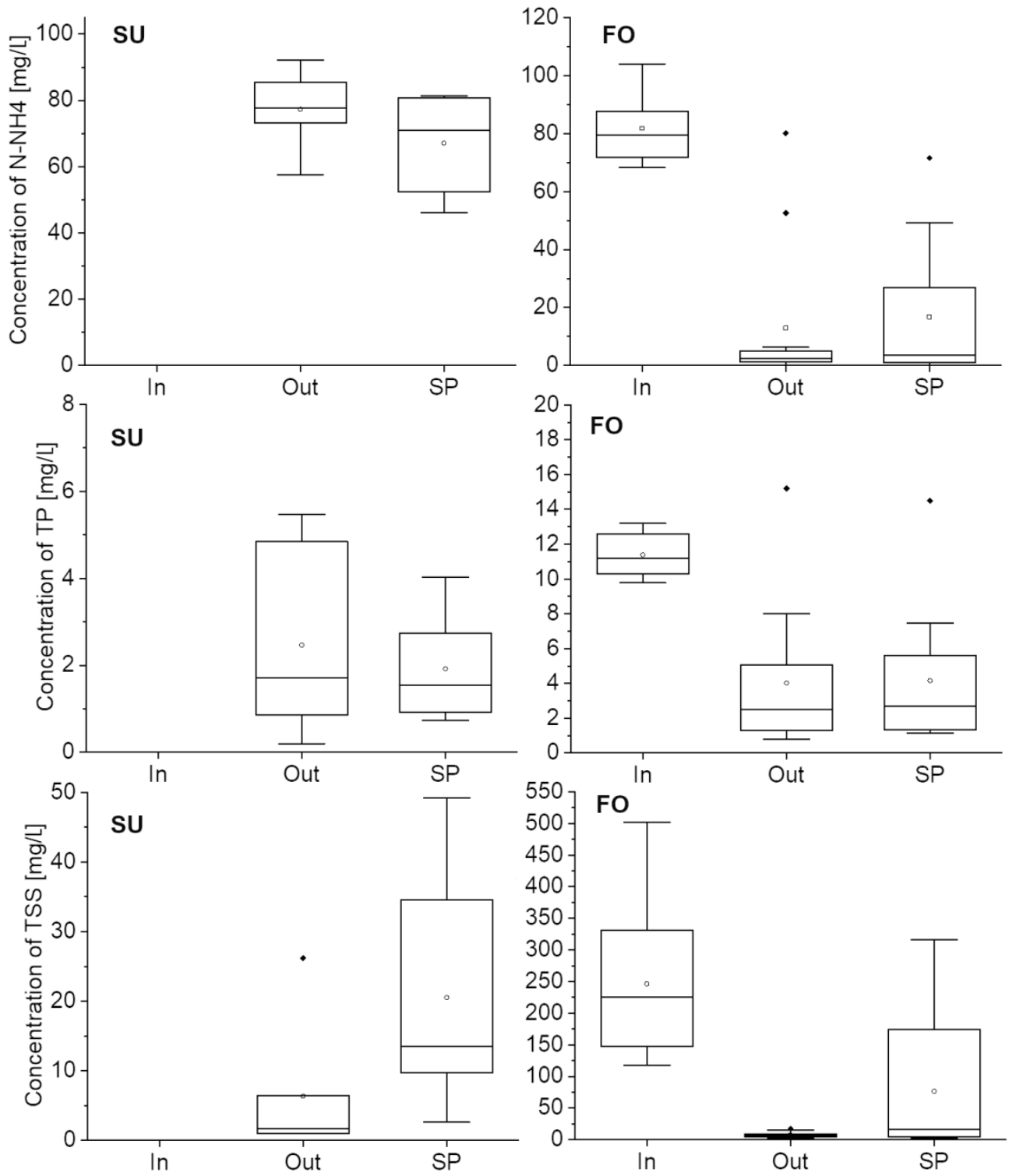

Figure 7. $\mathrm{N}-\mathrm{NH}_{4}{ }^{+}, \mathrm{TP}$ and TSS concentration comparison during SU = start-up phase and $\mathrm{FO}=$ full-scale operation, $\mathrm{In}=$ inlet, $\mathrm{Out}=$ outlet, $\mathrm{SP}=$ stabilization pond.

Table 4 summarizes the average concentrations of the monitored parameters at the inlet to the hybrid system and after purification in two stages-at the outlet and in the SP. The results in this table are valid for full operation only.

Table 4. Summarized operation performance of HCW during full operation.

\begin{tabular}{|c|c|c|c|c|c|c|}
\hline Year & $\begin{array}{c}\text { Limit AV/MAX } \\
{\left[\mathrm{mg} \cdot \mathrm{L}^{-1}\right]}\end{array}$ & In $\left[\mathbf{m g} \cdot \mathrm{L}^{-1}\right]$ & Out $\left[\mathrm{mg} \cdot \mathrm{L}^{-1}\right]$ & $\mathrm{SP}\left[\mathrm{mg} \cdot \mathrm{L}^{-1}\right]$ & Efficiency-Out [\%] & Efficiency-SP [\%] \\
\hline BOD & $30 / 40$ & $530.7 \pm 108.3$ & $5.6 \pm 5.0$ & $23.3 \pm 27.4$ & $99.0 \pm 0.9$ & $95.5 \pm 4.9$ \\
\hline COD & $130 / 150$ & $700.8 \pm 322.4$ & $53.0 \pm 42.6$ & $21.8 \pm 11.5$ & $91.4 \pm 6.4$ & $96.5 \pm 2.0$ \\
\hline TSS & $30 / 40$ & $246.4 \pm 117.2$ & $7.9 \pm 3.8$ & $101.0 \pm 109.1$ & $96.0 \pm 2.3$ & $44.5 \pm 69.8$ \\
\hline $\mathrm{TP}$ & $8 / 10$ & $11.4 \pm 1.2$ & $4.5 \pm 4.3$ & $4.7 \pm 4.2$ & $61.6 \pm 33.5$ & $60.0 \pm 32.3$ \\
\hline $\mathrm{TN}$ & $\mathrm{n} / \mathrm{a}$ & $102.1 \pm 17.3$ & $12.4 \pm 6.4$ & $11.1 \pm 7.5$ & $86.3 \pm 11.2$ & $87.1 \pm 13.0$ \\
\hline $\mathrm{N}-\mathrm{NH}_{4}{ }^{+}$ & $15 / 20$ & $81.8 \pm 12.3$ & $2.1 \pm 1.8$ & $1.9 \pm 1.7$ & $97.4 \pm 2.0$ & $97.3 \pm 1.6$ \\
\hline
\end{tabular}




\subsubsection{Pathogens}

The research focused on the removal of three indicator pathogenic bacteria-E. coli, intestinal enterococci and thermotolerant coliforms, with particular emphasis on the further use of the wastewater for the irrigation of crops. The results are summarized in Figure 8 . We observed statistically significant differences between the outlet concentrations of the monitored parameters at both sampling points in the start-up phase and during full operation. The E. coli concentrations were $14.7 \pm 14.0 \mathrm{CFU} \cdot \mathrm{mL}^{-1}$ at the Out and $28.5 \pm 27.0 \mathrm{CFU} \cdot \mathrm{mL}^{-1}$ in the SP during the start-up phase and, during full operation, $44.1 \pm 83.4 \mathrm{CFU} \cdot \mathrm{mL}^{-1}$ at the Out and $47.4 \pm 143.0 \mathrm{CFU} \cdot \mathrm{mL}^{-1}$ in the SP. We observed a significant decrease in $E$. coli (by 3 orders of magnitude) during the full operation compared to the inlet concentration of $9030 \pm 10,100 \mathrm{CFU} \cdot \mathrm{mL}^{-1}$. In the case of intestinal enterococci, we observed that the full operation resulted in a significant decrease in the presence of IE from an inlet content of $33.7 \pm 52.9 \mathrm{CFU} \cdot \mathrm{mL}^{-1}$ to $1.6 \pm 2.0 \mathrm{CFU} \cdot \mathrm{mL}^{-1}$ at the outlet and $1.5 \pm 1.2 \mathrm{CFU} \cdot \mathrm{mL}^{-1}$ in the SP. The total coliforms decreased by two to three orders of magnitude during full-scale operation from a concentration of $12,900 \pm 13,000 \mathrm{CFU} \cdot \mathrm{mL}^{-1}$ at the inlet to $73.0 \pm 110.0 \mathrm{CFU} \cdot \mathrm{mL}^{-1}$ at the outlet and $278.0 \pm 861.0 \mathrm{CFU} \cdot \mathrm{mL}^{-1}$ in the SP. The differences between the contents of pathogenic bacteria at the outlet sampling points were not significant in terms of any of the parameters.
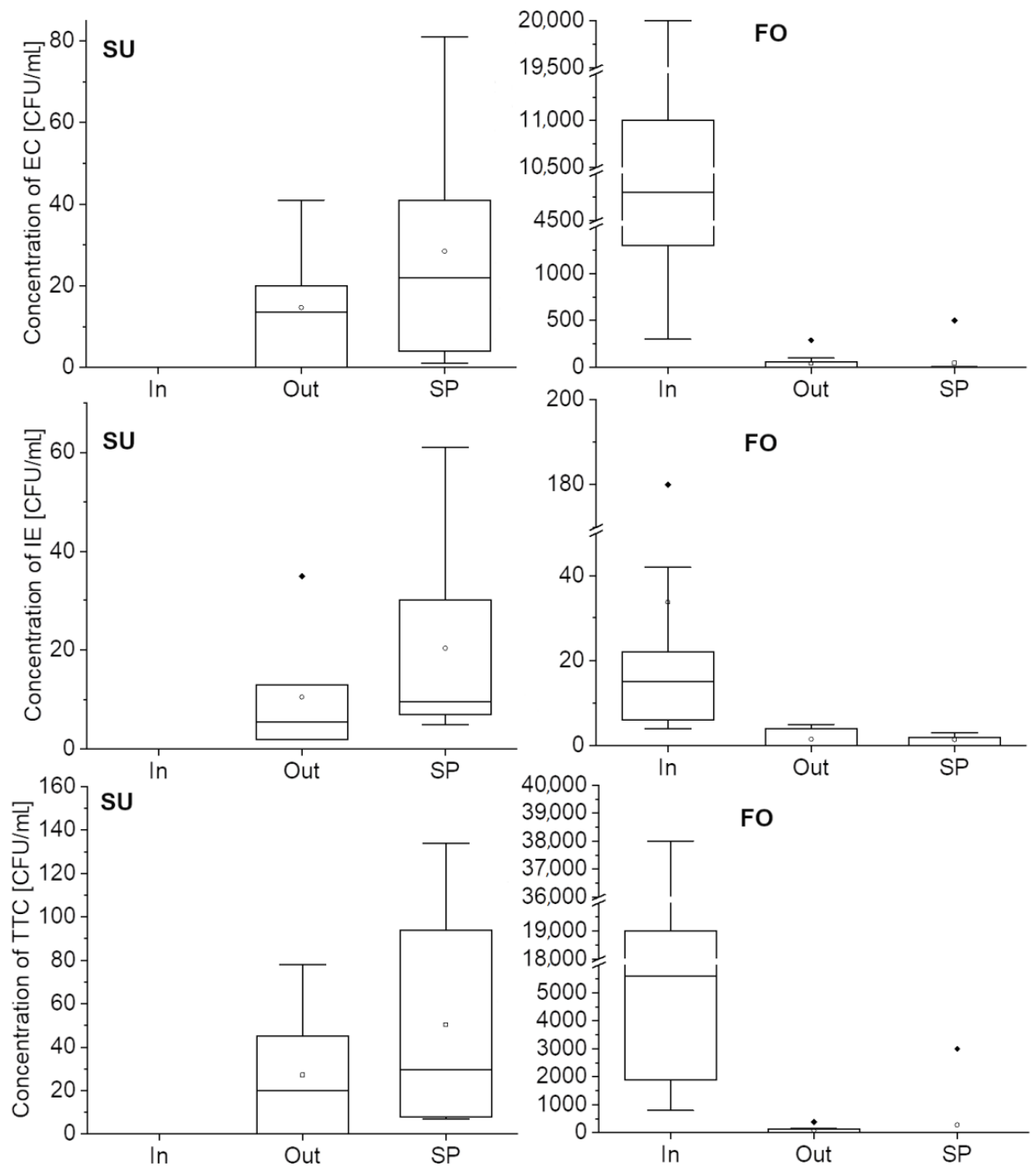

Figure 8. Pathogen concentration comparison during $\mathrm{SU}=$ start-up phase and $\mathrm{FO}=$ full-scale operation, $\mathrm{In}=$ inlet, Out $=$ outlet, $\mathrm{SP}=$ stabilization pond. 
Generally, inlet concentrations of the microbiological parameters measured are lower than typical values in domestic wastewater, since the HCW facility received a mixture of domestic wastewater, restaurant effluent and an agro-industrial effluent (brewery wastewater). Though the removal of pathogenic germs is not typically the main design target of $\mathrm{CW}$ systems, removal of pathogenic microorganisms takes place through various chemical (e.g., oxidation, UV radiation by sunlight, exposure to plant biocides), physical (e.g., filtration, sedimentation), and biological (e.g., predation, biolytic processes, natural die-off) processes [35], as indicated by the high removal rate detected along the wetland stages in the present study.

\subsection{Irrigation Tests}

\subsubsection{Yield}

The use of treated wastewater from the HCW for the irrigation of agricultural crops revealed promising results. The quality and fertilization effect of the water used for irrigation is shown in Table 5. The volume of water used for irrigation did not differ significantly between years. However, there is a noticeable difference in the amount of total organic matter and nitrogen supplied from the treated wastewater in the growing season of 2018, due to the poorer functionality of the HCW.

Table 5. Quality of the irrigation water sources.

\begin{tabular}{|c|c|c|c|c|c|c|}
\hline Year & Water Source & $\begin{array}{c}\text { Total Volume } \\
\qquad\left[\mathrm{m}^{3}\right]\end{array}$ & $\begin{array}{c}\text { TOC } \\
{\left[\mathrm{mg} \cdot \mathrm{L}^{-1}\right]}\end{array}$ & $\begin{array}{c}\mathrm{TP} \\
{\left[\mathrm{mg} \cdot \mathrm{L}^{-1}\right]}\end{array}$ & $\begin{array}{c}\mathrm{TN} \\
{\left[\mathrm{mg} \cdot \mathrm{L}^{-1}\right]}\end{array}$ & $\begin{array}{c}\text { TK } \\
{\left[\mathrm{mg} \cdot \mathrm{L}^{-1}\right]}\end{array}$ \\
\hline \multirow{6}{*}{2018} & Treated WW & 14.2 & $69.4 \pm 43.3$ & $3.8 \pm 4.0$ & $30.7 \pm 32.0$ & $71.1 \pm 10.2$ \\
\hline & Fresh Water & 14.2 & $5.8 \pm 4.2$ & 0.0 & $24.6 \pm 24.3$ & $51.3 \pm 4.7$ \\
\hline & & {$\left[\mathrm{m}^{3} /\right.$ plot $]$} & [kg/plot] & [kg/plot] & [kg/plot] & [kg/plot] \\
\hline & Treated WW & 7.1 & 0.492 & 0.027 & 0.217 & 0.504 \\
\hline & Fresh Water & 7.1 & 0.041 & 0.000 & 0.174 & 0.363 \\
\hline & Precipitation & 2.9 & - & - & - & - \\
\hline \multirow{6}{*}{2019} & Treated WW & 15 & $15.9 \pm 9.6$ & $5.2 \pm 4.6$ & $12.7 \pm 8.4$ & $63.2 \pm 17.5$ \\
\hline & Fresh Water & 15 & $5.4 \pm 1.2$ & $0.1 \pm 0.02$ & $8.1 \pm 2.6$ & $39.9 \pm 13.4$ \\
\hline & & {$\left[\mathrm{m}^{3} /\right.$ plot $]$} & [kg/plot] & [kg/plot] & [kg/plot $]$ & [kg/plot] \\
\hline & Treated WW & 7.5 & 0.119 & 0.038 & 0.094 & 0.471 \\
\hline & Fresh Water & 7.5 & 0.041 & 0.001 & 0.061 & 0.297 \\
\hline & Precipitation & 3.0 & - & - & - & - \\
\hline
\end{tabular}

TOC $=$ total organic carbon, $\mathrm{TN}=$ total nitrogen, $\mathrm{TP}=$ total phosphorus, $\mathrm{TK}=$ potassium.

As can clearly be seen in Table 6, all the crops-tomatoes, potatoes and lettuce-irrigated with treated wastewater provided significantly higher total yields. While the average weight of the tomatoes in the first season was similar under both variants, the total harvested yield was $4 \%$ higher following irrigation with the WW. However, in the second year of testing the harvested yield of tomatoes was 133\% higher following irrigation with the treated WW, and the average weight of the tomatoes was 31.6\% higher. The difference between the yields in the two seasons was most likely due to the previous depletion of nutrients naturally present in the soil at the site and the clearly favorable effect of irrigation with the purified WW on the total yield. Although the amounts of nutrients added via irrigation with the treated WW were significantly higher than those provided in the fresh water (see Table 4), the content of nutrients (N, P, K) in the tomatoes irrigated with the WW did not differ from the contents of nutrients in the tomatoes irrigated with fresh water.

Similarly, with respect to the potatoes, we observed significantly higher yields following irrigation with the WW. The total yield of biomass was almost 4 times higher and the average weight of the potatoes $76 \%$ higher when irrigated with WW than when treated with fresh water. However, again, the content of nutrients in the biomass did not differ between the two irrigation approaches.

Finally, the lettuce yield followed the trend of the other crops with a significantly higher yield (104\%) and average plant weight (107\%) following WW treatment than following fresh water irrigation. Similarly, the nutrient content did not differ between the two irrigation methods. 
Table 6. Harvesting data from the irrigation field experiment.

\begin{tabular}{|c|c|c|c|c|c|c|c|c|}
\hline Crop (Year) & Treatment & $\begin{array}{c}\text { Amount } \\
\text { of Fruit } \\
\text { [no.] }\end{array}$ & $\begin{array}{c}\text { Weight } \\
\text { of Fruit } \\
\text { [g] }\end{array}$ & $\begin{array}{l}\text { DM } \\
{[\%]} \\
\end{array}$ & $\begin{array}{c}\text { Total } \\
\text { Biomass } \\
{\left[g_{D M}\right]}\end{array}$ & $\begin{array}{l}\text { TN } \\
{[\%]}\end{array}$ & $\begin{array}{c}\text { TP } \\
{[\%]}\end{array}$ & $\begin{array}{l}\text { TK } \\
{[\%]} \\
\end{array}$ \\
\hline \multirow{2}{*}{ Tomato (2018) } & $\mathrm{CW}$ & 294 & $78.6 \pm 21.7$ & $6.2 \pm 0.4$ & 1526.1 & $0.16 \pm 0.00$ & $0.15 \pm 10.19$ & $2.01 \pm 69.13$ \\
\hline & Fresh water & 283 & $79.3 \pm 20.1$ & $6.3 \pm 0.3$ & 1466.9 & $0.16 \pm 0.00$ & $0.15 \pm 14.68$ & $2.11 \pm 69.75$ \\
\hline \multirow{2}{*}{ Tomato (2019) } & $\mathrm{CW}$ & 628 & $61.7 \pm 9.6$ & $7.5 \pm 0.0$ & 2877.3 & $0.07 \pm 0.02$ & $0.26 \pm 0.03$ & $2.19 \pm 0.11$ \\
\hline & Fresh water & 373 & $46.9 \pm 21.0$ & $7.3 \pm 0.0$ & 1234.5 & $0.06 \pm 0.01$ & $0.26 \pm 0.02$ & $1.98 \pm 0.10$ \\
\hline \multirow{2}{*}{ Potato (2019) } & $\mathrm{CW}$ & 207 & $68.7 \pm 21.8$ & $18.1 \pm 0.9$ & 1580.9 & $0.18 \pm 0.01$ & $0.57 \pm 0.02$ & $4.43 \pm 0.24$ \\
\hline & Fresh water & 116 & $39.0 \pm 17.4$ & $14.4 \pm 0.3$ & 408.4 & $0.19 \pm 0.01$ & $0.59 \pm 0.02$ & $4.12 \pm 0.08$ \\
\hline \multirow{2}{*}{ Lettuce (2019) } & CW & 21 & $311.0 \pm 81.3$ & $5.5 \pm 1.5$ & 452.3 & $0.12 \pm 0.02$ & $0.34 \pm 0.02$ & $1.52 \pm 0.07$ \\
\hline & Fresh water & 12 & $150.3 \pm 68.0$ & $6.8 \pm 2.7$ & 222.3 & $0.08 \pm 0.02$ & $0.34 \pm 0.03$ & $2.23 \pm 0.40$ \\
\hline
\end{tabular}

$\mathrm{DM}=$ dry matter, $\mathrm{TN}=$ total nitrogen, $\mathrm{TP}=$ total phosphorus, $\mathrm{TK}=$ potassium.

The results thus provide convincing proof that HCW-processed WW has a high fertilization potential due to the presence of $\mathrm{N}, \mathrm{P}$ and $\mathrm{K}$ and other micro-nutrients.

\subsubsection{Pathogens}

In the Czech Republic, the quality of water used for irrigation is regulated by the standard ČSN 757143 [36], which divides the quality of water for irrigation into 3 classes, namely Class I-water suitable for irrigation, Class II-water conditionally suitable for irrigation (time limit from end of irrigation until the harvest of crops) and Class III-water unsuitable for irrigation. Microbiological indicators defining the applicability class are given in Table 7. For all microbiological parameters of treated wastewater except TTC the water meets the conditions of use for irrigation in class II. Fresh water is also class II, as only in the case of enterococci have the conditions of class I been met. In the case of TTC, it is water in class III. For this reason, even in this case, it is necessary to observe the same harvesting conditions as for wastewater. The mentioned time limit from irrigation to harvest is 14 days for vegetables of all species that must be peeled, cooked or washed before consumption and 21 days for species consumed raw, but only after washing [36].

Table 7. Limits for Pathogen content in irrigation water given by Czech standard [36].

\begin{tabular}{cccc}
\hline Parameter & $\begin{array}{c}\text { Class I } \\
{\left[\mathbf{C F U} \cdot \mathbf{m L}^{-\mathbf{1}}\right]}\end{array}$ & $\begin{array}{c}\text { Class II } \\
{\left[\mathbf{C F U} \cdot \mathbf{m L}^{-\mathbf{1}}\right]}\end{array}$ & $\begin{array}{c}\text { Class III } \\
{\left[\mathbf{C F U} \cdot \mathbf{m L}^{-\mathbf{1}} \text { ] }\right.}\end{array}$ \\
\hline $\begin{array}{c}\text { Coliform bacteria } \\
\text { Faecal (thermotolerant) coliforms }\end{array}$ & 100 & 1000 & $>1000$ \\
Enterococci & 10 & 100 & $>100$ \\
\hline
\end{tabular}

With respect to the results of the microbiological analysis of the irrigation water conducted regularly at the irrigation system pumping station, no significant differences were observed in terms of the hygienic quality of the treated WW and the fresh water used for the control variants (see Figure 9). In the case of the harvested crops, the differences in the water source quality were somewhat "blurred" and the hygienic quality of the harvested crops was observed to be approximately the same for both irrigation variants. In other words, the replacement of fresh water with treated WW does not result in an increase in risk.

With respect to the potatoes, we observed a significantly higher content of IE; however, this difference could not be explained by the difference in the quality of the irrigation water. The most probable explanation was that the secondary contamination of the samples occurred during handling or, less likely, an episodic fluctuation occurred in the quality of the fresh water used for irrigation. The presence of E. coli was observed only for the lettuce harvest, with average concentrations in the order of the first hundreds of CFU. $\mathrm{g}_{\mathrm{DM}}{ }^{-1}$ for both irrigation approaches. Due to the single harvesting of the lettuce and potatoes, the question remains as to whether the contamination of the crops following the two irrigation approaches was a measurement error due to secondary contamination during harvesting 
or was due to the inappropriate subsequent handling of the samples. More data are listed in Table 8.

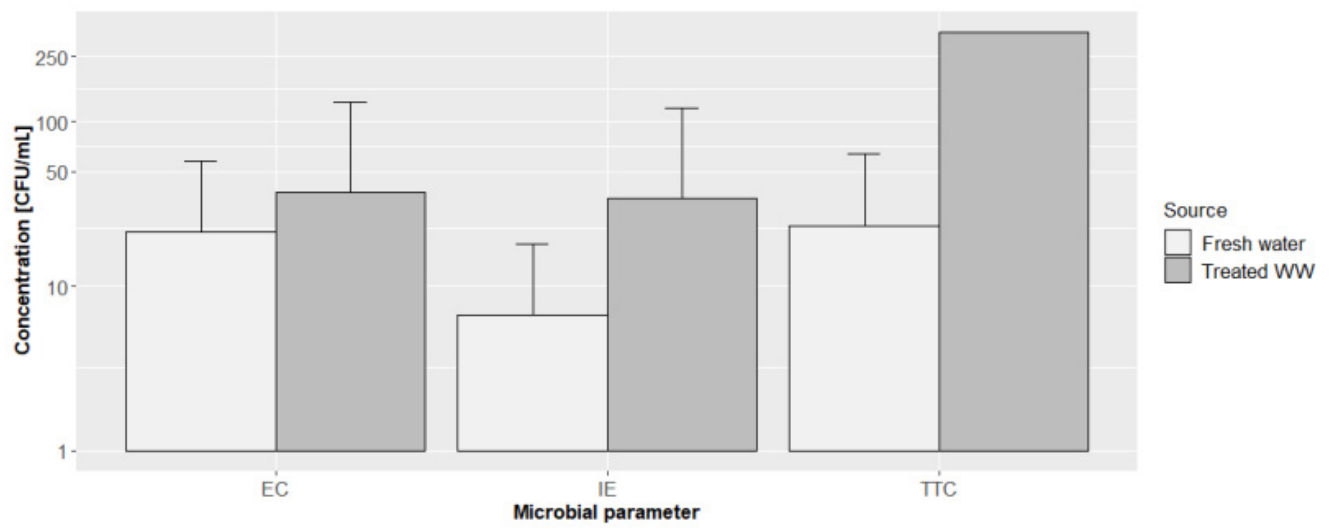

Figure 9. Quality of the two irrigation water types in terms of the content of thermotolerant coliforms (TTC), Escherichia coli (EC) and intestinal enterococci (IE).

Table 8. Harvest data from the irrigation field experiment.

\begin{tabular}{|c|c|c|c|c|}
\hline Year/Crop & Treatment & $\begin{array}{l}\text { Escherichia coli } \\
{\left[\mathrm{CFU} \cdot \mathrm{g}_{\mathrm{DM}}{ }^{-1}\right]}\end{array}$ & $\begin{array}{c}\text { Intestinal Enterococci } \\
{\left[\mathrm{CFU} \cdot \mathrm{g}_{\mathrm{DM}}{ }^{-1}\right]}\end{array}$ & $\begin{array}{c}\text { Thermotolerant Coliforms } \\
{\left[\mathrm{CFU} \cdot \mathrm{g}_{\mathrm{DM}}{ }^{-1}\right]}\end{array}$ \\
\hline \multirow{2}{*}{ Tomato (2018) } & $\mathrm{CW}$ & $0.0 \pm 0.0$ & $0.0 \pm 0.0$ & $0.0 \pm 0.0$ \\
\hline & Fresh water & $0.0 \pm 0.0$ & $70.8 \pm 108.9$ & $20.8 \pm 38.0$ \\
\hline \multirow{2}{*}{ Tomato (2019) } & $\mathrm{CW}$ & $0.0 \pm 0.0$ & $40.0 \pm 49.9$ & $8.9 \pm 19.1$ \\
\hline & Fresh water & $0.0 \pm 0.0$ & $46.7 \pm 68.0$ & $36.3 \pm 60.7$ \\
\hline \multirow{2}{*}{ Potato (2019) } & $\mathrm{CW}$ & $0.0 \pm 0.0$ & $0.0 \pm 0.0$ & $\mathrm{n} / \mathrm{a}$ \\
\hline & Fresh water & $0.0 \pm 0.0$ & $1290.0 \pm 1824.3$ & $\mathrm{n} / \mathrm{a}$ \\
\hline \multirow{2}{*}{ Lettuce (2019) } & $\mathrm{CW}$ & $75.8 \pm 86.7$ & $201.7 \pm 162.8$ & $161.7 \pm 160.4$ \\
\hline & Fresh water & $320.0 \pm 47.6$ & $346.7 \pm 47.1$ & $543.3 \pm 48.2$ \\
\hline
\end{tabular}

\section{Discussion}

The main aim of this study was to describe the potential of hybrid constructed wetlands for the non-potable reuse of treated wastewater in the agriculture sector. The inlet and outlet concentrations of six chemical parameters and three microbiological parameters were studied for the assessment of the efficiency of an HCW in terms of purifying wastewater to the stage at which it can be used for irrigation purposes. Hence, an experimental field was established and used for the irrigation of selected crops (tomatoes, potatoes and lettuce), the results of which allowed for the description of both the fertilizing effect of the treated WW and the potential hygiene risks.

Wastewater reclamation is one of a number of non-conventional solutions being considered worldwide aimed at easing water scarcity issues caused by climate change [37]. In decentralized semi-arid and arid areas particularly, where wastewater makes up a considerable percentage of irrigation water [38], it is important that simple but effective wastewater treatment technologies are developed. Responsible treatment approaches assist in mitigating the risks associated with the application of WW to the soil [39] and, moreover, the reuse of wastewater effluents helps in the recycling of nutrients and the protection of water bodies [40]. It is very important to carefully consider the irrigation method applied. In this study, the drip irrigation approach was applied, which is both efficient and uses only around half the water required by other conventional methods [41].

While many countries worldwide are adopting diverse legal limits for the minimum quality of water used for irrigation [42], the European Commission is proposing to harmonize the rules applied within the EU via the implementation of Regulation of the European Parliament and of the Council on minimum requirements for water reuse 2018/0169/COD [43]. According to this regulatory proposal, minimum reclaimed water 
quality will be divided into classes defined by crop category and based on the form of consumption (raw, boiled) as well as the potential for direct contact with the wastewater (Table 1 of the regulation proposal [43]). The existing Czech standard [36], which regulates the quality of irrigation water, does not consider the use of treated wastewater. For this reason this study assessed the performance of the HCW according to the proposed EU regulation.

The studied hybrid constructed wetland evinced a high level of organic pollution removal efficiency. The removal of $\mathrm{BOD}_{5}$ and COD amounted to $99.0 \pm 0.9 \%$ and $91.4 \pm 6.4 \%$, respectively, which is comparable to other hybrid systems with horizontal and vertical filters in series with reported [44] removal efficiency levels of $\mathrm{BOD}_{5}$ of $92.7 \pm 10.3 \%$ and of COD $88.8 \pm 10.2 \%$. The high organic pollution removal rate was ensured by employing unsaturated vertical filters and the simple recirculation of the wastewater; however, the separate effects of these two factors were difficult to distinguish. Total suspended solids were removed at a very high removal rate of $96.0 \pm 2.3 \%$ and the outlet concentrations corresponded to the results of other studies [14]. However, the effluent water was observed to be very sensitive to changes in the TSS. We observed a significant increase in TSS concentrations in the stabilization pond due to the growth of algae. This factor thus plays an important role in terms of choosing the most suitable location for the pumping of irrigation water aimed at preventing the clogging of the irrigation distribution system. The outlet $\mathrm{BOD}_{5}$ and TSS concentrations with respect to full operation were $5.6 \pm 5.0$ and $7.9 \pm 3.8 \mathrm{mg} \cdot \mathrm{L}^{-1}$, which means that the water quality met A class reclaimed water quality requirements as set out in the relevant regulation [43]. However, the irrigation water considered in the study was pumped from the $\mathrm{SP}$, where the $\mathrm{BOD}_{5}$ and TSS concentrations were $23.3 \pm 27.4$ and $101.0 \pm 109.1 \mathrm{mg} \cdot \mathrm{L}^{-1}$, respectively. In this case, the WW met the requirements of the C-D quality class, concerning which limits are set according to EU Council directive 91/271/EEC: a limit value for $\mathrm{BOD}_{5}$ of $<25 \mathrm{mg} \cdot \mathrm{L}^{-1}$ and for TSS $35-60 \mathrm{mg} \cdot \mathrm{L}^{-1}$. Thus, we recommend the extraction of irrigation water directly from the outflow and not from the stabilization pond.

The removal of nitrogen comprises one of the most important advantages of hybrid systems. Moreover, this parameter is not limited solely to reclamation. Ammonia nitrogen, which made up $85 \%$ of $\mathrm{TN}$, was removed at a $97.4 \pm 2.0 \%$ efficiency rate, while the TN removal was just $86.3 \pm 11.2 \%$. At the same time, $\mathrm{N}-\mathrm{NH}_{4}{ }^{+}$made up just $26 \%$ of $\mathrm{TN}$ at the outlet. Our findings in this respect are higher than those determined in other published hybrid system studies $[45,46]$, in which removals of $83-89 \%$ and $78-83 \%$ for $\mathrm{N}-\mathrm{NH}_{4}{ }^{+}$and $\mathrm{TN}$, respectively have been reported. The results remain, however, significantly higher than those obtained from traditional horizontal sub-surface flow CWs with reported removals of $\mathrm{N}-\mathrm{NH}_{4}{ }^{+}$and of $\mathrm{TN}$ of just $40.4 \%$ and $33.9 \%$, respectively [47]. Our results clearly show that unsaturated filters with aerobic conditions comprise the most important factor in terms of the efficient removal of nitrogen [11]. Moreover, the oxidation of the $\mathrm{N}-\mathrm{NH}_{4}{ }^{+}$in the $\mathrm{HCW}$ led to the creation of other nitrogen forms that provided mixtures of nitrate and ammonia that are more beneficial to plant growth [48].

Generally, the removal of TP by constructed wetlands is limited. Vymazal (2013) [44] reported the removal of TP in similar hybrid systems of $74 \pm 13 \%$, while our study determined a removal of TP of $86.3 \pm 11.2 \%$. Moreover, the removal of TP was independent of the configuration of the components of the HCW. The outlet concentrations of TP were determined at $4.5 \pm 4.3 \mathrm{mg} \cdot \mathrm{L}^{-1}$ which, if limited, do not fulfil the required standards for the discharge of wastewater. However, for the purpose of the reuse of non-potable wastewater, the remaining nutrient concentrations provide a number of benefits, especially if one considers WW reclamation as an alternative to other biological and chemical resource recovery technologies such as microalgae, macrophyte, struvite, etc. [49].

An important parameter that points to the advantage of this technology is the low acquisition and operating costs compared to conventional systems. As part of the evaluation of the operation of the HCW system, the costs for the acquisition and operation of the treatment plant were calculated. With an estimated useful life of 30 years, the total annual cost (capital and O\&M) is $4026 €$. This corresponds to an annual cost of $26.8 €$ per PE or 
$0.67 €$ per $\mathrm{m}^{3}$ of treated water. These are operating costs comparable to other $\mathrm{CW}$ systems. Tsihrintzis et al. (2007) [50], for example, states the operating costs of the free water surface system at $22.7 €$ per PE, while for the vertical subsurface flow CW it states a cost of $36.8 €$ per PE. Thus, implementation of modern hybrid CWs do not represent significantly higher operating costs.

The removal of pathogens comprises one of the most important factors in terms of reclamation. Many authors have reported removal rates for pathogens in constructed wetlands of as high as $99.99 \%$ [51]. This study revealed a removal efficiency of $99.5 \%$ at the outlet, with similar results in the stabilization pond for Escherichia coli, i.e., 95.4\%, for intestinal enterococci, $95.7 \%$, and $99.4 \%$ and $97.8 \%$ for the thermotolerant coliforms. The outlet concentrations of EC, IE and TTC were determined at $44.09,1.55$ and $73.00 \mathrm{CFU} \cdot \mathrm{mL}^{-1}$, respectively and the SP concentrations of EC, IE and TTC at 47.36, 1.45 and $277.55 \mathrm{CFU} \cdot \mathrm{mL}^{-1}$, respectively. According to [43] the HCW effluent fulfils the quality requirements of class $C$ reclaimed water (crops consumed raw, the above-ground edible parts of which are not in direct contact with the reclaimed water when using only the drip irrigation method). Similar or even higher concentrations of pathogens were observed in the reclaimed wastewater studied in [52], which employed a drip system to irrigate tomatoes, lettuce and fennel with treated municipal wastewater.

The yields of the crops were significantly higher following irrigation with the reclaimed WW, particularly in the second season for the tomato plants. As evinced by other similar studies $[4,40,52]$, the weight of the harvested plants was higher following irrigation with reclaimed WW than with fresh water. Moreover, the yields would probably have been even higher if fertilizers had been used in addition to the nutrients added by the wastewater [40]. The fact that the amount of nutrients available for the plants did not exceed typical doses of nutrients provided by fertilizers was evident from the content of $\mathrm{N}, \mathrm{P}$ and $\mathrm{K}$ in the crop tissues. In particular, the content of $\mathrm{N}$ was at least one order lower than reported in other studies [40,53]. Moreover, no significant differences were observed in the $\mathrm{N}, \mathrm{P}$ and $\mathrm{K}$ contents between the plants irrigated with wastewater and those with fresh water. The fecal contamination of the plants was reflected by the content of E. coli, intestinal enterococci and thermotolerant coliforms on the surface of the plants. E. coli contamination was proven only in the case of the lettuce plants. However, EC contamination was also detected on the plants irrigated with fresh water. Similarly, we observed the plant surface contamination of the tomatoes, potatoes and lettuce by intestinal enterococci even following irrigation by fresh water. Similar findings for tomatoes and lettuce were reported in $[52,54]$ also following the fresh water irrigation of the plants. Such findings thus serve to contextualize the risks associated with the microbial contamination of plants irrigated by wastewater. Nevertheless, it is important to note that these findings also indicate that such plants should not be used without proper washing and cooking, and that reclaimed wastewater should not be used for irrigation purposes when the edible part of the plant may come into contact with the water [55].

\section{Conclusions}

The results of this study demonstrate that the use of wastewater for irrigation can lead to significant savings in the consumption of fresh water for irrigation of agricultural crops as well as savings in the application of fertilizers. It is thus a suitable tool for adaptation to climate change and to preserve groundwater and surface water resources. The study also showed that hybrid constructed wetlands are able to provide for adequate wastewater treatment and sanitation at a level of efficiency that is comparable to other conventional systems. Nevertheless, it is necessary to be aware of the various safety measures related to the potential contamination of crops via fecal indicator microorganisms, including those that are not normally considered in such research. Thus, in conclusion, the issues considered in the study provide significant potential for future research. 
Author Contributions: Conceptualization, M.Š., P.I. and T.H.; Data curation, P.I., M.R. and J.S.; Formal analysis, A.S.; Funding acquisition, T.H.; Investigation, M.R.; Methodology, M.Š. and T.C.; Project administration, M.Š. and J.S.; Resources, T.H.; Supervision, T.H.; Visualization, M.Š.; Writingoriginal draft, M.Š.; Writing - review \& editing, A.S. and T.C. All authors have read and agreed to the published version of the manuscript.

Funding: This research was funded by Technology agency of the Czech Republic, grant number TJ04000322 and TH02030583 and by Center for Geosphere Dynamics (UNCE/SCI/006).

Institutional Review Board Statement: Not applicable.

Informed Consent Statement: Not applicable.

Data Availability Statement: Data is contained within the article.

Acknowledgments: Thanks go to Darren Ireland for the language correction of the English text.

Conflicts of Interest: The authors declare no conflict of interest. The funders had no role in the design of the study; in the collection, analyses, or interpretation of data; in the writing of the manuscript, or in the decision to publish the results.

\section{References}

1. Echchelh, A.; Hess, T.; Sakrabani, R.; Prigent, S.; Stefanakis, A.I. Towards agro-environmentally sustainable irrigation with treated produced water in hyper-arid environments. Agric. Water Manag. 2021, 243, 106449. [CrossRef]

2. Stefanakis, A.I. Constructed Wetlands for Sustainable Wastewater Treatment in Hot and Arid Climates: Opportunities, Challenges and Case Studies in the Middle East. Water 2020, 12, 1665. [CrossRef]

3. Hamilton, A.J.; Stagnitti, F.; Xiong, X.; Kreidl, S.L.; Benke, K.K.; Maher, P. Wastewater Irrigation: The State of Play. Vadose Zone J. 2007, 6, 823-840. [CrossRef]

4. Al-Lahham, O.; El Assi, N.; Fayyad, M. Impact of treated wastewater irrigation on quality attributes and contamination of tomato fruit. Agric. Water Manag. 2003, 61, 51-62. [CrossRef]

5. Capra, A.; Scicolone, B. Recycling of poor quality urban wastewater by drip irrigation systems. J. Clean. Prod. 2007, 15, 1529-1534. [CrossRef]

6. Gatica, J.; Cytryn, E. Impact of treated wastewater irrigation on antibiotic resistance in the soil microbiome. Environ. Sci. Pollut. Res. 2013, 20, 3529-3538. [CrossRef]

7. Svobodová, K.; Semerád, J.; Petráčková, D.; Novotný, Č. Antibiotic Resistance in Czech Urban Wastewater Treatment Plants: Microbial and Molecular Genetic Characterization. Microb. Drug Resist. 2018, 24, 830-838. [CrossRef] [PubMed]

8. Kostich, M.S.; Batt, A.L.; Lazorchak, J.M. Concentrations of prioritized pharmaceuticals in effluents from 50 large wastewater treatment plants in the US and implications for risk estimation. Environ. Pollut. 2014, 184, 354-359. [CrossRef] [PubMed]

9. Semerád, J.; Hatasová, N.; Grasserová, A.; Černá, T.; Filipová, A.; Hanč, A.; Innemanová, P.; Pivokonský, M.; Cajthaml, T. Screening for 32 per- and polyfluoroalkyl substances (PFAS) including GenX in sludges from 43 WWTPs located in the Czech Republic-Evaluation of potential accumulation in vegetables after application of biosolids. Chemosphere 2020, $261,128018$. [CrossRef] [PubMed]

10. Wu, S.; Carvalho, P.N.; Müller, J.A.; Manoj, V.R.; Dong, R. Sanitation in constructed wetlands: A review on the removal of human pathogens and fecal indicators. Sci. Total. Environ. 2016, 541, 8-22. [CrossRef]

11. Stefanakis, A.I. Constructed wetlands: Description and benefits of an eco-tech water treatment system. In Impact of Water Pollution on Human Health and Environmental Sustainability; McKeown, A.E., Bugyi, G., Eds.; IGI GLobal: Hershey, PA, USA, 2016; pp. 281-303; ISBN 9781466695603.

12. Stefanakis, A. The Role of Constructed Wetlands as Green Infrastructure for Sustainable Urban Water Management. Sustainability 2019, 11, 6981. [CrossRef]

13. Vymazal, J. Horizontal sub-surface flow and hybrid constructed wetlands systems for wastewater treatment. Ecol. Eng. 2005, 25, 478-490. [CrossRef]

14. Ayaz, S.Ç.; Aktaş, Ö.; Akça, L.; Fındık, N. Effluent quality and reuse potential of domestic wastewater treated in a pilot-scale hybrid constructed wetland system. J. Environ. Manag. 2015, 156, 115-120. [CrossRef] [PubMed]

15. Borin, M.; Politeo, M.; De Stefani, G. Performance of a hybrid constructed wetland treating piggery wastewater. Ecol. Eng. 2013, 51, 229-236. [CrossRef]

16. Stefanakis, A. Constructed Wetlands for Industrial Wastewater Treatment; John Wiley \& Sons Ltd.: Chichester, UK, 2018; ISBN 9781119268413.

17. Šereš, M.; Hnátková, T.; Maršík, P.; Vaněk, T.; Soudek, P.; Vymazal, J. Field Study VI: The Effect of Loading Strategies on Removal Efficiencies of a Hybrid Constructed Wetland Treating Mixed Domestic and Agro-Industrial Wastewaters; Springer: Cham, Switzerland, 2020; pp. 395-409.

18. Comino, E.; Riggio, V.; Rosso, M. Grey water treated by an hybrid constructed wetland pilot plant under several stress conditions. Ecol. Eng. 2013, 53, 120-125. [CrossRef] 
19. Vymazal, J.; Březinová, T. The use of constructed wetlands for removal of pesticides from agricultural runoff and drainage: A review. Environ. Int. 2015, 75, 11-20. [CrossRef]

20. Ruppelt, J.P.; Pinnekamp, J.; Tondera, K. Elimination of micropollutants in four test-scale constructed wetlands treating combined sewer overflow: Influence of filtration layer height and feeding regime. Water Res. 2020, 169, 115214. [CrossRef]

21. Ávila, C.; García, J. Pharmaceuticals and Personal Care Products (PPCPs) in the Environment and Their Removal from Wastewater through Constructed Wetlands. Compr. Anal. Chem. 2015, 67, 195-244. [CrossRef]

22. Šereš, M.; Rozkošný, M.; Hudcová, H.; Šalanda, P.; Innemanová, P.; Sedláček, P.S. The application of treated wastewater for the irrigation of fast-growing trees-field experiments on constructed wetland. Waste Forum 2019, 4, 350-360.

23. ISO. ISO 6060:1989-Water Quality-Determination of the Chemical Oxygen Demand. Available online: https://www.iso.org/ standard/12260.html (accessed on 21 April 2021).

24. ISO. ISO 5815-1:2019-Water Quality—Determination of Biochemical Oxygen Demand after n Days (BODn)—Part 1: Dilution and Seeding Method with Allylthiourea Addition. Available online: https://www.iso.org/standard/69058.html (accessed on 21 April 2021).

25. ISO. ISO 5815-2:2003-Water Quality—Determination of Biochemical Oxygen Demand after n Days (BODn)—Part 2: Method for Undiluted Samples. Available online: https://www.iso.org/standard/31091.html (accessed on 21 April 2021).

26. ISO. ISO 6878:2004-Water Quality-Determination of Phosphorus-Ammonium Molybdate Spectrometric Method. Available online: https: / /www.iso.org/standard/36917.html (accessed on 21 April 2021).

27. ECS. EN 12260:2003-Water Quality—Determination of Nitrogen—Determination of Bound Nitrogen (TNb), Following Oxidation to Nitrogen Oxides. Available online: https: / www.en-standard.eu/une-en-12260-2004-water-quality-determination-ofnitrogen-determination-of-bound-nitrogen-tnb-following-oxidation-to-nitrogen-oxides/ (accessed on 21 April 2021).

28. ISO. ISO 7150-1:1984-Water Quality—Determination of Ammonium-Part 1: Manual Spectrometric Method. Available online: https: / / www.iso.org/standard/13742.html (accessed on 21 April 2021).

29. ECS. ISO 11923:1997 Water Quality—Determination of Suspended Solids by Filtration through Glass-Fibre Filters. Available online: https:/ / www.iso.org/standard/20654.html (accessed on 21 April 2021).

30. Fremrová, L.; Baudišová, D. ČSN 757837 (757837)—Water Quality—Determination of Coliform Bacteria in Non-Disinfected Waters; Czech Office for Standards, Metrology and Testing: Prague, Czech Republic, 2010.

31. ISO. ISO 7899-2:2000-Water Quality—Detection and Enumeration of Intestinal Enterococci-Part 2: Membrane Filtration Method. Available online: https:/ /www.iso.org/standard/14854.html (accessed on 21 April 2021).

32. ISO. ISO 16634-2:2016-Food Products-Determination of the Total Nitrogen Content by Combustion According to the Dumas Principle and Calculation of the Crude Protein Content-Part 2: Cereals, Pulses and Milled Cereal Products. Available online: https:/ / www.iso.org/standard/66661.html (accessed on 21 April 2021).

33. ISO. ISO 11885:2007-Water Quality-Determination of Selected Elements by Inductively Coupled Plasma Optical Emission Spectrometry (ICP-OES). Available online: https://www.iso.org/standard/36250.html (accessed on 21 April 2021).

34. Gomes, A.C.; Silva, L.; Albuquerque, A.; Simões, R.; Stefanakis, A.I. Investigation of lab-scale horizontal subsurface flow constructed wetlands treating industrial cork boiling wastewater. Chemosphere 2018, 207, 430-439. [CrossRef]

35. Stefanakis, A.I.; Akratos, C.S. Removal of pathogenic bacteria in Constructed Wetlands: Mechanisms and efficiency. In Phytoremediation: Management of Environmental Contaminants, Volume 4; Ansari, A.A., Gill, S.S., Gill, R., Lanza, G.R., Newman, L., Eds.; Springer International Publishing: Cham, Switzerland, 2016; pp. 327-346. ISBN 9783319418117.

36. Zavadil, J.; Pasler, J. Czech Standard ČSN 75 7143-Water Quality for Irrigation; Czech Office for Standards, Metrology and Testing: Prague, Czech Republic, 1991.

37. Nikolaou, G.; Neocleous, D.; Christou, A.; Kitta, E.; Katsoulas, N. Implementing Sustainable Irrigation in Water-Scarce Regions under the Impact of Climate Change. Agronomy 2020, 10, 1120. [CrossRef]

38. Zhang, Y.; Shen, Y. Wastewater irrigation: Past, present, and future. Wiley Interdiscip. Rev. Water 2019, 6, e1234. [CrossRef]

39. Travis, M.J.; Wiel-Shafran, A.; Weisbrod, N.; Adar, E.; Gross, A. Greywater reuse for irrigation: Effect on soil properties. Sci. Total. Environ. 2010, 408, 2501-2508. [CrossRef]

40. Urbano, V.R.; Mendonça, T.G.; Bastos, R.G.; Souza, C.F. Effects of treated wastewater irrigation on soil properties and lettuce yield. Agric. Water Manag. 2017, 181, 108-115. [CrossRef]

41. Chaware, D.; Panse, M.; Raut, A.; Koparkar, A. Sensor Based Automated Irrigation System. IJERT 2015, 4, 33-37.

42. Drewes, J.E.; Hübner, U.; Zhiteneva, V.; Karakurt, S. Characterization of Unplanned Water Reuse in the EU Final Report; Garching, Germany, 2017. Available online: https:/ / op.europa.eu/en/publication-detail/-/publication/e73cd97d-78c3-11e7-b2f2-01aa7 5ed71a1/language-en/format-PDF\#document-info (accessed on 21 April 2021).

43. EC 2018/0169 Regulation of the European Parliament and of the Council on Minimum Requirements for Water Reuse; European Parliament: Brussels, Belgium, 2018.

44. Vymazal, J. The use of hybrid constructed wetlands for wastewater treatment with special attention to nitrogen removal: A review of a recent development. Water Res. 2013, 47, 4795-4811. [CrossRef] [PubMed]

45. Vymazal, J.; Kröpfelová, L. Multistage hybrid constructed wetland for enhanced removal of nitrogen. Ecol. Eng. 2015, 84, 202-208. [CrossRef]

46. Wu, S.; Kuschk, P.; Brix, H.; Vymazal, J.; Dong, R. Development of constructed wetlands in performance intensifications for wastewater treatment: A nitrogen and organic matter targeted review. Water Res. 2014, 57, 40-55. [CrossRef] 
47. Vymazal, J.; Kröpfelová, L. Removal of Nitrogen in Constructed Wetlands with Horizontal Sub-Surface Flow: A Review. Wetlands 2009, 29, 1114-1124. [CrossRef]

48. Hachiya, T.; Sakakibara, H. Interactions between nitrate and ammonium in their uptake, allocation, assimilation, and signaling in plants. J. Exp. Bot. 2017, 68, 2501-2512. [CrossRef] [PubMed]

49. Musfique, A.; Chowdhury, H.K.; Hafizur, R.; Ali Hossain, M.; Sheikh, A.U. Prospects of using wastewater as a resource-nutrient recovery and energy generation. Am. J. Environ. Sci. 2015, 11, 99-114. [CrossRef]

50. Tsihrintzis, V.A.; Akratos, C.S.; Gikas, G.D.; Karamouzis, D.; Angelakis, A.N. Performance and Cost Comparison of a FWS and a VSF Constructed Wetland System. Environ. Technol. 2007, 28, 621-628. [CrossRef]

51. Weber, K.P.; Legge, R.L. Pathogen removal in constructed wetlands. In Wetlands: Ecology, Conservation E Restoration; Russo, R.E., Ed.; Nova Science Publisher, Inc.: Hauppauge, NY, USA, 2008; p. 20. ISBN 9781604569957.

52. Lonigro, A.; Rubino, P.; Lacasella, V.; Montemurro, N. Faecal pollution on vegetables and soil drip irrigated with treated municipal wastewaters. Agric. Water Manag. 2016, 174, 66-73. [CrossRef]

53. Mukta, S.; Rahman, M.; Mortuza, M. Yield and Nutrient Content of Tomato as Influenced by the Application of Vermicompost and Chemical Fertilizers. J. Environ. Sci. Nat. Resour. 2016, 8, 115-122. [CrossRef]

54. Libutti, A.; Gatta, G.; Gagliardi, A.; Vergine, P.; Pollice, A.; Beneduce, L.; Disciglio, G.; Tarantino, E. Agro-industrial wastewater reuse for irrigation of a vegetable crop succession under Mediterranean conditions. Agric. Water Manag. 2018, 196, 1-14. [CrossRef]

55. Yin, H.; Nou, X.; Gu, G.; Patel, J. Microbiological quality of spinach irrigated with reclaimed wastewater and roof-harvest water. J. Appl. Microbiol. 2018, 125, 133-141. [CrossRef] [PubMed] 